\title{
Is Greed Ever Good?: Royal Commission's Impact on Agriculture Loans in Australia
}

\author{
Michael A Adams* \\ Head of UNE Law School, Australia \\ *Corresponding author: Michael A Adams, Head of UNE Law School, Australia
}

\section{Opinion}

In 2013, the media broke a scandal about the Commonwealth Bank of Australia (CBA) financial planning arm having corrupt practices. This led to a Senate Inquiry and by July 2014 there were loud calls for a royal commission. The next few years saw the momentum peak with CBA again being caught by AUSTRAC (the agency for anti-money laundering and terrorism financing) with 54,000 breaches of the law by way of their intelligent ATM network. Former High Court Justice, Kenneth Hayne, was appointed by the Governor General to conduct the Royal Commission in the Misconduct of Banking, Superannuation and Financial Services Industry, through 2018 and report by 1st February 2019. Public interest in the Banking Royal Commission (BRC) has been extraordinary, with over 10,000 public submissions, 30 background academic papers on the various issues, 20,000 exhibits at public hearings and over 4.5 million page views of the BRC website. The four major banks plus Macquarie Bank, make up half of the top ten ASX listed companies, with a combined market capital of over $\$ 400$ billion. Most superannuation funds are invested in the top 50 ASX companies and the majority of home mortgages and business loans are via the four main banks.

The interim report in September 2018 expressly stated the need to follow six principles: obey the law; do not mislead; be fair; provide fit for purpose services; take reasonable care/skill and act in others best interests.

There were 76 specific recommendations in the Final Report, which cross the sectors of banking, financial advice, superannuation, insurance, the regulators and the crucial areas of culture, governance and remuneration. The Federal Government released a response on 4th February (the day the BRC report was made public) called "Restoring trust in Australia's financial system". The government and opposition, knowing this is an election year, agreed to all the recommendations, but the devil will be in the detail. Many of the amendments relate to banking and the application of the Banking Executive Accountability Scheme, to hold executives responsible for their employees and other entities liable. The regulators have been directed to have a "why not litigate" approach rather than negotiating to settle effectively criminal matters. But Commissioner Hayne's wish for a simplification and clarity of the existing laws will have to be seen through new drafting in legislation. Additionally, the impact of remuneration policies that really promoted greed and ignored customers/clients best interests, needs to be dramatically changed.

Separate to the BRC was an Australian Securities and Investments Commission (ASIC - lead corporate regulator) Taskforce on enforcement, which recommended more deterrent powers. The BRC endorsed these new laws and thus the maximum penalties jumped from $\$ 220,000$ to $\$ 1.05$ million for individuals and corporations from $\$ 1$ million to $\$ 10.4$ million (or $10 \%$ of revenue up to $\$ 525$ million). The biggest penalty, being a jail sentence from five years to 15 years maximum. These new laws commenced on the 12th March 2019. ASIC has created an Office of Enforcement to coordinate the litigation and investigations on civil penalty and criminal matters, with the Commonwealth Director of Public prosecutions. This is a step in the right direction. The cultural requirements will take time to be processed but I hope the agricultural loan recommendations are fast tracked. It seems sensible that there is a national debt mediation scheme and experienced agricultural bank managers, should be involved in such negotiations. That drought or other natural disasters, that are declared, should remove interest penalties and other distortions for farm loans. But as always, the details have not yet been released, and we will need to see them before final judgment can be made.

In the area of agricultural and farm loans, the BRC Commissioner hayne had some specific recommendations:

Recommendation 1.11 - farm debt mediation

Recommendation 1.12 - valuation of land

Recommendation 1.13 - charging default interest

Recommendation 1.14 - distressed agricultural loans 


\section{What Does This Mean in Practice?}

This is in fact good news for both the corporate and family farmer businesses throughout Australia that have been impacted by drought and floods; as well as inappropriate lending practices of the major banks. To clarify more there has been a push for a national scheme of farm debt mediation for some time and this is recommended to be enacted into law by Parliament. The Federal Government has responded by agreeing to establish this farm debt mediation scheme that would assist both lenders and borrowers to agree on practical measures to address financial difficulties. The mediation should be activated as soon as the loan becomes distressed and not as a last measure before enforcement, such as foreclosure. At this point in time, few details of such a scheme have been provided. The valuation of land relates to the prudential regulator, APRA amending Prudential Standard 220 for the valuation of land as a security for a loan to take into account external events that impact on the realizable value of the property. This should be considered throughout the loan decision process. The Government supports this amendment and will instruct APRA to act on this amendment. This could have credit lending implications for farmers, as loans require security based upon a valuation. Recommendation 1.13 deals with the charging of default interest payments and Commissioner Hayne recommended that the Australian Banking Association (ABA) should amend the Banking Code (that will be legally enforceable), so that banks cannot charge a default interest on loans secured by agricultural land. The proviso is linked to a declaration that the land is subject to drought or other natural disaster. The Government supports the ABA in making this amendment to the Code.

Finally,many farmerwill begladtosee aspecific recommendation (1.14) relating to distressed agricultural loans at this current time of drought for much of the country, and Far North Queensland's floods and other natural disasters. The recommendation requires banks, when dealing with distressed agricultural loans to only use experienced agricultural bankers and offer farm debt mediation as soon as possible. Additionally, to manage the distressed loan on the basis of the best outcome for the borrower and the bank, rather than the remedy of the appointment of an external administrator. Finally ceasing charging default interest when there is no realistic prospect of recovering the amount charge (thus linked to recommendation 1.13). The Government supports the bank acting on this recommendation, but as yet has not released any draft legislation or amending legislation. The assessment of these agricultural recommendations is that overall, these are sensible and practical and should be implemented as soon as practical. It is hoped that all sides of the political spectrum would support these amendments and schemes, irrespective of the up-coming Federal election in May 2019. This is the start of reform and the biggest move has to be in the culture of organisations, especially banks, which have taken its customers for granted and allowed revenue tied to remuneration to drive everything - the 1980s mantra from Gordon Gecko's character in the Wall Street movie, has come back to haunt the 2007-2018 decade. We can do much better.

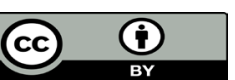

This work is licensed under Creative Commons Attribution 4.0 License

To Submit Your Article Click Here: Submit Article

DOI: $10.32474 /$ CIACR.2019.06.000243

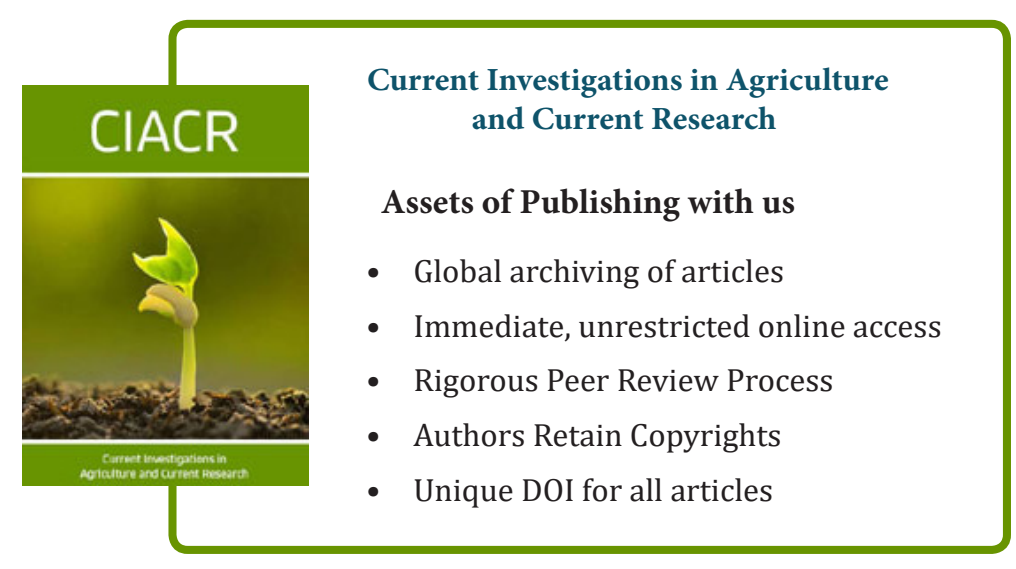

